\title{
End-Permian extinction amplified by plume-induced release of recycled lithospheric volatiles
}

DOI:

10.1038/s41561-018-0215-4

\section{Document Version}

Accepted author manuscript

Link to publication record in Manchester Research Explorer

\section{Citation for published version (APA):}

Broadley, M., Barry, P. H., Ballentine, C. J., Taylor, L. A., \& Burgess, R. (2018). End-Permian extinction amplified by plume-induced release of recycled lithospheric volatiles. Nature Geoscience, 11(9), 682-687. https://doi.org/10.1038/s41561-018-0215-4

\section{Published in:}

Nature Geoscience

\section{Citing this paper}

Please note that where the full-text provided on Manchester Research Explorer is the Author Accepted Manuscript or Proof version this may differ from the final Published version. If citing, it is advised that you check and use the publisher's definitive version.

\section{General rights}

Copyright and moral rights for the publications made accessible in the Research Explorer are retained by the authors and/or other copyright owners and it is a condition of accessing publications that users recognise and abide by the legal requirements associated with these rights.

\section{Takedown policy}

If you believe that this document breaches copyright please refer to the University of Manchester's Takedown Procedures [http://man.ac.uk/04Y6Bo] or contact uml.scholarlycommunications@manchester.ac.uk providing relevant details, so we can investigate your claim.

\section{OPEN ACCESS}


1 End-Permian extinction amplified by plume-induced release of recycled lithospheric volatiles

$4 \quad$ Michael W. Broadley ${ }^{1 \dagger}$; Peter H. Barry ${ }^{3}$; Chris J. Ballentine ${ }^{3}$; Lawrence A. Taylor ${ }^{4}$; Ray Burgess ${ }^{1}$

6

$7{ }^{1}$ School of Earth and Environmental Sciences, The University of Manchester, Manchester M13 9PL, UK

${ }^{3}$ Department of Earth Sciences, University of Oxford, Oxford, OX1 3AN, UK

${ }^{4}$ Department of Earth and Planetary Science, The University of Tennessee, Knoxville, TN 37996-1410, USA

† Present address: Centre de Recherches Pétrographiques et Géochimiques, 54501 
Magmatic volatile release to the atmosphere can lead to climatic changes and significant environmental degradation including the production of acid rain, ocean acidification and ozone depletion, potentially resulting in collapse of the biosphere. The largest recorded mass extinction in Earth's history occurred at the end-Permian, coinciding with the emplacement of the Siberian large igneous province, suggesting that large-scale magmatism is a key driver of global environmental change. However, the source and nature of volatiles in the Siberian large igneous province remain contentious. Here we present halogen compositions of sub-continental lithospheric mantle xenoliths emplaced prior to, and after the eruption of the Siberian flood basalts. We show that the Siberian lithosphere is massively enriched in halogens from the infiltration of subducted seawater-derived volatiles and that a significant amount (up to $70 \%$ ) of lithospheric halogens are assimilated into the plume and released to the atmosphere during emplacement. Plume-lithosphere interaction is therefore a key process controlling the volatile content of large igneous provinces and as such the extent of environmental crises, leading to mass extinctions during their emplacement.

Large igneous provinces (LIP) are the product of rapid eruptions of large volumes of magma over short geological time scales. The Permo-Triassic Siberian flood basalts (SFB) erupted $\sim 4 \times 10^{6} \mathrm{~km}^{3}$ of basalt in less than $1 \mathrm{Ma}^{1}$. The eruption of the SFB is contemporaneous with the main stage of the end-Permian crisis and is hypothesized to have contributed to environmental changes that resulted in loss of $>90 \%$ of all marine, and $>70 \%$ of all terrestrial species ${ }^{2,3}$. The end-Permian mass extinction has been attributed to sharp fluctuations in global temperatures and/or increased levels 
40 of ultraviolet radiation resulting from extensive ozone depletion both of which are 41 associated with the magmatic release of volatiles to the atmosphere ${ }^{2,4-7}$. Yet the 42 amount of volatiles expected to be released from the SFB assuming conventional 43 plume source magmatism is insufficient to account for the environmental degradation 44 and climatic fluctuations that occurred during the end-Permian crisis, requiring an 45 additional source of volatiles to be released during SFB emplacement ${ }^{8,9}$. To reconcile 46 the missing SFB volatiles, it has been variously argued for significant quantities of 47 volatiles released via contact metamorphism of a sedimentary sequence ${ }^{1,5}$; melting 48 of recycled eclogite within the mantle plume ${ }^{10}$; or melting of the cratonic lithosphere ${ }^{7}$. 49 However, the source of volatile species responsible for climatic fluctuations and 50 ozone depletion during the end-Permian crisis remains unknown.

52 Here we report the first detailed halogen $(\mathrm{Cl}, \mathrm{Br}$ and $\mathrm{I})$ data for peridotite xenoliths 53 from two Siberian kimberlites: one (Udachnaya, $360 \mathrm{Ma}$ ) emplaced before, and the 54 other (Obnazhennaya, $160 \mathrm{Ma}$ ) after the SFB eruption 250 Ma ${ }^{11,12}$ (Supplementary 55 Fig. 1). The Udachnaya peridotite xenoliths $(n=9)$ represent melt extraction from the 56 depleted cratonic mantle; whereas Obnazhennaya xenoliths $(n=6)$ contain both 57 Archean cratonic lithosphere and melt residues generated from the SFB plume 58 (Supplementary Information) ${ }^{13}$. Determining the halogen composition of the cratonic 59 sub-continental lithospheric mantle (SCLM; Udachnaya) and the SFB plume 60 residues (Obnazhennaya) provides a means to estimate the composition of the SFB 61 prior to eruption, and quantify the contribution of the lithospheric mantle to the 62 halogen budget of the SFB. 


\section{Lithospheric mantle as a reservoir for halogens}

65 Due to its isolation and non-convective nature, the SCLM retains geochemical

66 heterogeneities introduced through interactions with mantle, crustal and subduction-

67 related sources ${ }^{14,15}$. Metasomatic components infiltrating the SCLM are sampled by

68 mantle xenoliths. Rapidly transported to the surface during kimberlite volcanism,

69 these xenoliths provide a window into the composition and origin of SCLM volatiles ${ }^{16-}$

$70 \quad 18$.

72 The halogen and noble gas composition of the Udachnaya and Obnazhennaya 73 xenoliths was determined using neutron-irradiated noble gas mass spectrometry 74 (Methods). The results are summarised in Supplementary Tables 2 and 3 and 75 displayed in Fig. 1. The range of $\mathrm{Cl}, \mathrm{Br}$ and I concentrations within the Udachnaya 76 and Obnazhennaya xenoliths are significantly different, with the average 77 concentrations from crushing and step heating being consistently higher in 78 Udachnaya samples indicating they originate from distinct domains within the SCLM 79 (Supplementary Information). Halogen-bearing fluids present in the samples, as 80 indicated by release during crushing experiments, have a similar range of $\mathrm{Br} / \mathrm{Cl}$ and $81 \mathrm{I} / \mathrm{Cl}$ in both Udachnaya and Obnazhennaya xenoliths (Fig. 2a). During stepped82 heating of crushed residues the xenoliths show evidence for distinct endmember 83 halogen compositions (Fig. 2b). Udachnaya retains similar $\mathrm{Br} / \mathrm{Cl}$ and $\mathrm{l} / \mathrm{Cl}$ as 84 measured during crushing, whilst Obnazhennaya samples have more mantle-like $85 \mathrm{Br} / \mathrm{Cl}$ and $\mathrm{I} / \mathrm{Cl}$ values (Table S3). 
87 Previously published helium isotopic data also varies between the xenoliths suites,

88 with the average ${ }^{3} \mathrm{He} /{ }^{4} \mathrm{He}$ of Udachnaya $\left(0.4 \pm 0.3 \mathrm{R}_{\mathrm{A}}\right)$ consistently lower than

89 Obnazhennaya $\left(4.2 \pm 0.9 \mathrm{R}_{\mathrm{A}}\right)$, which has a maximum ${ }^{3} \mathrm{He} /{ }^{4} \mathrm{He}\left(8.4 \pm 0.3 \mathrm{R}_{\mathrm{A}}\right)$ similar

90 to mid ocean ridge basalts $(\mathrm{MORB})^{18} \cdot{ }^{3} \mathrm{He} /{ }^{4} \mathrm{He}, \mathrm{Br} / \mathrm{Cl}$ and $\mathrm{I} / \mathrm{Cl}$ values appear to be

91 coupled (Fig. 3), showing that fluids within the Obnazhennaya xenoliths represent a

92 mixture between a component rich in radiogenic ${ }^{4} \mathrm{He}, \mathrm{Br}$ and $\mathrm{I}$, and a component with

93 mantle-like ${ }^{3} \mathrm{He} /{ }^{4} \mathrm{He}$ and halogen compositions. The lower ${ }^{3} \mathrm{He} /{ }^{4} \mathrm{He}$ and elevated

$94 \mathrm{Br} / \mathrm{Cl}$ and $\mathrm{I} / \mathrm{Cl}$ as characterised by Udachnaya xenoliths, is considered representative

95 of the ancient metasomatised section of the SCLM (metasomes) that was present

96 before significant influence of the SFB mantle plume. In contrast, Obnazhennaya

97 also contains variable amounts of a mantle-like halogen and He component. Given

98 the similarity in rare earth elements (REE) patterns and extraction age for the

99 Obnazhennaya xenoliths with regards to the $\mathrm{SFB}^{13}$, it is considered that mantle-like

100 volatiles were added by the Siberian plume which interacted with the lithosphere

101 having a volatile composition characterised by fluids trapped in the Udachnaya

102 xenoliths (Fig. 3).

104 The initial inventory of halogens within the metasomatised section of Siberian SCLM

105 prior to plume impingement can be estimated using the composition of Udachnaya 106 xenoliths. The Siberian SCLM transitions from depleted harzburgite and Iherzolites to 107 predominantly metasomatised peridotites at $180-190 \mathrm{~km}^{19}$. Assuming that the 108 Udachnaya peridotite xenoliths are representative of metasomatised peridotites in 109 the lower $30 \mathrm{~km}$ of the SCLM, and taking the surficial area of the Siberian Craton $110\left(4 \times 10^{6} \mathrm{~km}^{2}\right)$, then the metasomatised portion of the Siberian SCLM contains 111 approximately $0.6-1.5 \times 10^{19}, 1.6-2.7 \times 10^{17}$ and $0.5-1.1 \times 10^{14} \mathrm{~kg}$ of $\mathrm{Cl}, \mathrm{Br}$ and I 
112 respectively (Supplementary Table 1 and Supplementary Information). The

113 metasomatised Siberian SCLM is therefore enriched in $\mathrm{Cl}, \mathrm{Br}$ and $\mathrm{I}$ by factors of up

114 to 125,675 and 100 times, respectively, relative to the depleted MORB mantle $115(\mathrm{DMM})^{20}$. Thus, the SCLM is a significantly larger and more heterogeneous halogen

116 reservoir than previously considered and may impart a significant influence on global 117 volatile cycles $^{21}$.

119 Release of lithospheric halogens during LIP emplacement

120 The comparatively large quantity of halogens residing in the base of the Siberian 121 SCLM means that even small proportions released to the surface will have 122 significant consequences for the global halogen cycle. The eruption of halogens into 123 the stratosphere catalyses ozone-destroying reactions, raising surface levels of 124 biologically damaging UV radiation ${ }^{22,23}$. Transit of the SFB plume through the SCLM 125 could potentially have liberated significant amounts of halogens and other volatiles to 126 the atmosphere, contributing to species decline and extinction during the end127 Permian crisis.

129 Udachnaya xenoliths formed at significantly deeper depths (>50km difference) $)^{17}$ in 130 the lithosphere compared to Obnazhennaya. The identification of Udachnaya-like 131 metasomatic signatures in Obnazhennaya indicates that volatiles residing in the 132 metasomatised basal SCLM were mobilised and ascended to shallower parts of the 133 SCLM. Obnazhennaya xenoliths have trace element signatures within the range of 134 previously reported values of the SFB ${ }^{17}$, strong P-PGE depletions uncharacteristic of 
135 cratonic lithosphere and Os isotopic compositions consistent with a formation age

136 similar to the time of plume impingement ${ }^{13}$. These characteristics indicate that the

137 part of the lithosphere sampled by the Obnazhennaya kimberlite represents the melt

138 residue of the SFB-plume (Fig. $4 d)^{13}$. The identification of metasomatised SCLM

139 signatures within the Obnazhennaya xenoliths therefore suggests that as the SFB

140 plume impacted the base of the lithosphere, the resulting melts incorporated volatiles

141 mobilised from the deeper metasomatised SCLM, before being erupted at the

142 surface or stalling in the lithosphere. The contribution of SCLM-derived volatiles to

143 the SFB plume can therefore be estimated using differences in halogen and noble

144 gas signatures between the Udachnaya (metasomatised SCLM) and Obnazhennaya

145 (SFB + metasomatised SCLM) xenoliths.

147 Assuming that the melt residues in the Obnazhennaya lithosphere had a starting 148 composition similar to the SFB plume $\left(12.7 \mathrm{R}_{\mathrm{A}} \text { and mantle-like } \mathrm{Br} / \mathrm{Cl} \text { and } \mathrm{l} / \mathrm{Cl}\right)^{24,25}$ 149 then the amount of assimilation from the SCLM (Udachnaya) can be estimated from 150 the extent of mixing between the two sources (Fig. 2, 3, Supplementary Information). 151 Comparing $\mathrm{He}, \mathrm{Br}$ and I systematics between the SFB plume and the SCLM 152 component represented by Udachnaya, requires that up to $70 \%$ of volatiles in 153 Obnazhennaya be derived from the SCLM (Fig. 3a,b, Supplementary Fig. 2). 154 Furthermore, any potential overprinting related to crustal assimilation affecting the 155 halogen composition of the melt can be excluded as the rapid transport of xenoliths 156 to the surface via kimberlite volcanism limits any potential interaction with the 157 surrounding crust $^{26,27}$. 
159 Taking the volume of $\mathrm{Cl}$ degassed as calculated from the SFB melt inclusions $160\left(8.7 \times 10^{15} \mathrm{~kg}\right)$, then the total fluxes of $\mathrm{Br}$ and I to the atmosphere are estimated to be $1612.3 \times 10^{13} \mathrm{~kg}$ and $9.6 \times 10^{10} \mathrm{~kg}$ respectively. This calculation assumes the melt had $162 \mathrm{Br} / \mathrm{Cl}$ and $\mathrm{I} / \mathrm{Cl}$ values similar to Obnazhennaya and considers that halogens are not 163 fractionated during degassing ${ }^{28}$. Explosive eruptions inject reactive $\mathrm{HCl}$ and $\mathrm{HBr}$ 164 gases into the lower stratosphere $(\sim 12-25 \mathrm{~km})$ and deplete ozone levels, whereas 165 effusive eruptions lead to soluble $\mathrm{HCl}$ being washed-out prior to reaching the 166 stratosphere ${ }^{24}$. Considering only explosive events $(20-30 \% \text { of the SFB })^{29}$, a $\sim 75 \%$ 167 rate of stratospheric injection ${ }^{30}$, and the amount of $\mathrm{Cl}$ measured within the $\mathrm{SFB}^{31}$, 168 then the mass of $\mathrm{Cl}$ released to the stratosphere over the main eruptive phase of the 169 SFB (two thirds of the total eruptive volume over $300 \mathrm{ky})^{32}$ is the equivalent to $0.5-1.0$ 170 Pinatubo (1991-1992) eruptions, which caused a $15-20 \%$ reduction in global 171 ozone $^{33}$, every year for $300 \mathrm{ky}$. Models of ozone depletion during the SFB eruption, 172 using estimated stratospheric $\mathrm{HCl}$ fluxes predict a $30-55 \%$ reduction in ozone over 173 the same eruptive timeframe ${ }^{4}$. These stratospheric $\mathrm{HCl}$ flux estimates are 5 times 174 lower than the predicted from the SFB melt inclusions $\left(8.7 \times 10^{15} \mathrm{~kg}\right)^{31}$. Furthermore, 175 these estimates do not take into account the consequences of $\mathrm{Br}$ degassing on 176 ozone depletion. The large release of $\mathrm{Br}$ to the stratosphere during the SFB, as 177 indicated by the high $\mathrm{Br} / \mathrm{Cl}$ of the Siberian SCLM, likely further exacerbated ozone 178 depletion. Bromine has a much greater capacity for depleting ozone ( $45 \times$ more 179 effective ${ }^{24}$ ) and could have reduced ozone levels by a further $20 \%$ during SFB 180 eruption. Although there are several uncertainties in the rate and magnitude of 181 volatile degassing during SFB magmatism, the scale of halogen degassing fluxes 182 presented here are sufficient to incur a near to total loss of global ozone during the 183 end-Permian crisis. 
184 Melt inclusions within the SFB contain between $0.01-0.33$ wt. $\% \mathrm{Cl}^{10,31}$, which is an 185 order of magnitude higher than the maximum measured $\mathrm{Cl}$ concentrations in other $186 \mathrm{LIPs}^{8,31}$. Inclusions with high $\mathrm{Cl}$ concentrations are found to be equally enriched in 187 other volatiles species such as fluorine (1.95 wt. \%) and sulphur $(0.51 \mathrm{wt} \text { \% })^{31}$. To 188 create such high volatile contents within these melts, starting from a DMM-like 189 composition, would require very low degree partial melting, or the assimilation of 190 volatiles from another unknown reservoir. Low degrees partial melting can 191 concentrate volatiles in the melt fraction, however the high Mg contents measured 192 within the melt inclusions preclude low degree partial melting, suggesting that the 193 assimilation of volatile-rich material is most likely cause of the high volatile contents 194 in the SFB.

The composition of the Obnazhennaya xenoliths, assumed to represent plume melt 197 residues, can be used to estimate the pre-eruptive SFB melt composition and 198 establish if the SCLM is the potential source of the SFB volatile enrichment. Obnazhennaya xenoliths require $\sim 30 \%$ melt extraction to account for the elevated $200 \mathrm{Fo}_{>92}$ of the olivines ${ }^{13}$ and therefore the $\mathrm{Cl}$ composition of this melt can be estimated 201 using a batch melting model ${ }^{34}$. Experimentally determined partition coefficients for $\mathrm{Cl}$ between olivine $\left(\mathrm{D}_{\mathrm{Cl}}{ }^{\mathrm{O} / \mathrm{Melt}}=1.9 \times 10^{-2}\right)$ and pyroxene $\left(\mathrm{D}_{\mathrm{Cl}}{ }^{\text {Pyx/Melt }}=1.5 \times 10^{-2}\right)$ were used

203 to calculate the $\mathrm{Cl}$ concentration of the melt at $1500^{\circ} \mathrm{C}$, prior to eruption ${ }^{35}$. Using the 204 range of $\mathrm{Cl}$ concentrations in the olivine and pyroxene minerals from Obnazhennaya 205 xenoliths yield $\mathrm{Cl}$ concentrations of $0.1-0.2 \mathrm{wt} \%$ in the melt. These estimates are 206 considered upper limits given the potential for an unknown proportion of intact fluid 207 inclusions to remain following crushing, thus $\mathrm{Cl}$ data based on stepped heating is 208 likely to overestimate the $\mathrm{Cl}$ abundance within the minerals. However, it is notable 
209 that the melt $\mathrm{Cl}$ estimates are consistent with previous values for the eruptive melt

210 composition $(0.01-0.33 \text { wt. } \% \mathrm{Cl})^{10,32}$ providing confidence in the assumptions we

211 have made and confirming that the SFB melt was already enriched in $\mathrm{Cl}$ prior to

212 eruption. These arguments therefore provide further (albeit indirect) support for a

213 SCLM origin for the majority of halogens in SFB melts.

\section{Implications for the end-Permian extinction}

216 Ozone depletion during the end-Permian crisis is considered to have led to the

217 decline in the dominant terrestrial plant species at the time, followed by the rapid

218 expansion of opportunistic lycopsids ${ }^{36}$. The global distribution of preserved

219 microspores from these emerging lycopsides exhibit features indicative of a failure in 220 the normal development process of the spores. The global dispersion of these

221 mutagenic spores suggest that this was a reaction to global stress factors, unlikely to

222 be related to changes in global temperature from the release of gases such as $\mathrm{SO}_{2}$

223 and $\mathrm{CO}_{2}$ during SFB emplacement ${ }^{4}$. Experiments on the effects of end-Permian UV-

224 B regimes on modern conifers led to a fivefold increases in the occurrence of 225 mutagenic malformations, and complete sterilisation ${ }^{37}$. This would have caused 226 widespread deforestation and the collapse of the terrestrial biosphere, indicating 227 ozone depletion was a major contributing factor in the end-Permian mass extinction 228 event $^{4,37}$.

230 The peak occurrence of mutagenic spores occurs prior to the rapid negative shift in

$231 \delta^{13} \mathrm{C}$ in end-Permian carbonates attributed to the extinction of calcified marine life ${ }^{36}$. 
232 The $\delta^{13} \mathrm{C}$ excursions coincide with a change from predominantly extrusive to

233 intrusive eruptions of the Siberian LIP ${ }^{1}$. The emplacement of sills into volatile rich

234 sediments was considered to have released vast quantities of volatiles including $\mathrm{CO}_{2}$

235 and halocarbons gases to the atmosphere leading to rapid climate change and

236 ozone depletion ${ }^{1,5}$. However, from the palynological evidence ${ }^{36}$ it is clear that a

237 reduction in terrestrial biodiversity was occurring prior to the onset of marine

238 extinction. Furthermore, evidence for reduced sedimentation rates prior to and up to

239 the PTB, indicates that there was global eustatic sea-level regression potentially

240 caused by falling global temperatures and the onset of glaciation ${ }^{38}$. The rapid fall in

241 temperatures has been linked to the emission of $\mathrm{SO}_{2}$ to the atmosphere during the

242 eruptive phase of the SFB ${ }^{7}$.

244 The concurrent timing of the eruptive phase of the SFB and the palynological

245 evidence for ozone depletion is not consistent with the idea of sedimentary brines

246 degassing during later intrusive phases of igneous activity being the primary source

247 of halogens causing ozone destruction. As we have shown in this study the majority

248 of halogens in the SFB were added during plume-lithosphere interaction followed by

249 their subsequent release to the atmosphere during explosive eruptions. Sulphur

250 enrichments, co-existing with halogens in $\mathrm{SFB}^{31}$, may also have been derived from

251 the SCLM (Fig. 4c). Evidence for terrestrial species decline prior to PTB therefore

252 suggests that the release of halogens and gaseous sulphur species, and the

253 subsequent decline in ozone and global temperatures respectively were the

254 predominant factors in initiating the end-Permian mass extinction. The change in

255 eruptive phase from explosive to intrusive may have played a role in extending the

256 extinction from a mainly terrestrial phenomenon to a global extinction event. 


\section{Subducted origin of volatiles in the Siberian lithosphere}

259 The high concentrations of halogens in the Udachnaya xenoliths indicate the 260 Siberian SCLM has been enriched in volatiles by metasomatic processes. 261 Udachnaya xenoliths have $\mathrm{Br} / \mathrm{Cl}$ and $\mathrm{I} / \mathrm{Cl}$ similar to fluids trapped within minerals in

262 the altered oceanic crust (AOC), suggesting that the metasomatism of the Siberian 263 SCLM was potentially driven by subduction derived fluids (Fig. 2) ${ }^{39}$. Combined with 264 the noble gases (Fig. 3; Supplementary Fig. 3 and 4) the Udachnaya xenoliths show 265 an evolution from seawater-like ${ }^{3} \mathrm{He} /{ }^{4} \mathrm{He}, \mathrm{Br} / \mathrm{Cl}$ and $\mathrm{l} / \mathrm{Cl}$ values, to values with 266 increasingly radiogenic ${ }^{3} \mathrm{He} /{ }^{4} \mathrm{He}$ and enriched $\mathrm{Br} / \mathrm{Cl}$ and $\mathrm{I} / \mathrm{Cl}$ (Fig. 3), further 267 suggesting that the metasomatic fluid originated as seawater but subsequently 268 evolved, during subduction or within the SCLM, due to halogen fractionation and the 269 production of ${ }^{4} \mathrm{He}$ from U-Th decay ${ }^{18}$. Eclogite xenoliths from the Udachnaya 270 kimberlite exhibit $\delta^{18} \mathrm{O}$ up to $+7.7 \%{ }^{40}$, outwith the normal mantle range $(+5.4 \pm$ $2710.2 \%)^{41}$ indicating that they originated as oceanic crust that underwent low 272 temperature alteration ${ }^{40}$. Eclogites formed from the subduction of oceanic crust have 273 been shown to retain the halogen and oxygen isotopic signature of the oceanic crust 274 protolith during metamorphism, providing a mechanism for the delivery of 275 subduction-derived halogens to the Siberian SCLM ${ }^{42,43}$.

277 As we have shown in this study, up to $70 \%$ of the volatile content of the Siberian 278 plume originated from assimilation of metasomatised lithospheric material. The 279 composition of the SCLM therefore plays an integral role in controlling the volatile 280 content of LIPs, and as such the overall effect they have on the global environment. 
281 Based on the evolution of the $\mathrm{Br} / \mathrm{Cl}, \mathrm{I} / \mathrm{Cl}$ and ${ }^{3} \mathrm{He} /{ }^{4} \mathrm{He}$ of the xenoliths from seawtaer

282 to AOC-like values, coupled with the AOC-like $\delta^{18} \mathrm{O}$ within eclogites xenoliths from

283 Udachnaya, its appears that the origin of the Siberian SCLM volatiles is from the 284 subduction of a seawater derived component within the AOC. Enrichment of 285 seawater-derived volatiles in the Siberian SCLM provided the plume with an 286 abundant supply of halogens, which were released to the atmosphere during 287 eruption and resulted in globally extensive reductions in ozone levels and the decline 288 of the biosphere. The SCLM is also a major repository for other subducted volatile 289 species including sulphur and carbon $^{44,45}$, which can also contribute to environmental 290 degradation during plume-lithosphere interaction and LIP emplacement ${ }^{7}$. The SCLM 291 can therefore act as a repository of subducted volatile that can periodically be 292 mobilised and released to the Earth's surface and atmosphere during deep-seated 293 melting and volcanism leading to devastating impacts on the global environment.

\section{References}

2961 Burgess, S., Muirhead, J. \& Bowring, S. Initial pulse of Siberian Traps sills as the 297 trigger of the end-Permian mass extinction. Nature Communications 8 (2017).

2992 Wignall, P. B. Large igneous provinces and mass extinctions. Earth-science reviews $300 \quad 53,1-33(2001)$.

3023 Erwin, D. H., Bowring, S. A. \& Yugan, J. End-Permian mass extinctions: a review. 303 Special Paper - Geological Soceity of America, 363-384 (2002). 
3054 Beerling, D. J., Harfoot, M., Lomax, B. \& Pyle, J. A. The stability of the stratospheric 306 ozone layer during the end-Permian eruption of the Siberian Traps. Philosophical

307 Transactions of the Royal Society of London A: Mathematical, Physical and

$308 \quad$ Engineering Sciences 365, 1843-1866 (2007).

309

3105 Svensen, H. et al. Siberian gas venting and the end-Permian environmental crisis.

311 Earth and Planetary Science Letters 277, 490-500 (2009).

312

3136 Grard, A., Francois, L., Dessert, C., Dupré, B. \& Godderis, Y. Basaltic volcanism and 314 mass extinction at the Permo-Triassic boundary: environmental impact and modeling 315 of the global carbon cycle. Earth and Planetary Science Letters 234, 207-221 (2005).

3177 Guex, J. et al. Thermal erosion of cratonic lithosphere as a potential trigger for mass318 extinction. Scientific reports 6, 23168 (2016).

319

3208 Self, S., Widdowson, M., Thordarson, T. \& Jay, A. E. Volatile fluxes during flood 321 basalt eruptions and potential effects on the global environment: A Deccan 322 perspective. Earth and Planetary Science Letters 248, 518-532 (2006).

3249 Sobolev, A., Sobolev, S., Kuzmin, D., Malitch, K. \& Petrunin, A. Siberian 325 meimechites: origin and relation to flood basalts and kimberlites. Russian Geology 326 and Geophysics 50, 999-1033 (2009).

32810 Sobolev, S. V. et al. Linking mantle plumes, large igneous provinces and environmental catastrophes. Nature 477, 312 (2011). 
33111 Reichow, M. K. et al. ${ }^{40} \mathrm{Ar} /{ }^{39} \mathrm{Ar}$ dates from the West Siberian Basin: Siberian flood basalt province doubled. Science 296, 1846-1849 (2002).

333

12 Ivanov, A. V. et al. Siberian Traps large igneous province: Evidence for two flood basalt pulses around the Permo-Triassic boundary and in the Middle Triassic, and contemporaneous granitic magmatism. Earth-Science Reviews 122, 58-76 (2013).

337

338

13 Pernet-Fisher, J. et al. Plume impingement on the Siberian SCLM: Evidence from Re-Os isotope systematics. Lithos 218, 141-154 (2015).

340

14 Walker, R., Carlson, R., Shirey, S. \& Boyd, F. Os, Sr, Nd, and Pb isotope systematics of southern African peridotite xenoliths: implications for the chemical evolution of subcontinental mantle. Geochimica et Cosmochimica Acta 53, 1583-

345

15 McDonough, W. Constraints on the composition of the continental lithospheric mantle. Earth and Planetary Science Letters 101, 1-18 (1990).

16 Taylor, L. A., Milledge, H. J., Bulanova, G. P., Snyder, G. A. \& Keller, R. A. Metasomatic eclogitic diamond growth: evidence from multiple diamond inclusions. International Geology Review 40, 663-676 (1998).

35317 Howarth, G. H. et al. Superplume metasomatism: evidence from Siberian mantle xenoliths. Lithos 184, 209-224 (2014). 
35618 Barry, P. H. et al. Helium isotopic evidence for modification of the cratonic lithosphere during the Permo-Triassic Siberian flood basalt event. Lithos 216, 73-80

358 (2015).

359

19 Griffin, W., Fisher, N., Friedman, J., O'Reilly, S. Y., \& Ryan, C. (2002). Crpyrope garnets in the lithospheric mantle 2. Compositional populations and their distribution in time and space. Geochemistry, Geophysics, Geosystems,

20 Kendrick, M. et al. Seawater cycled throughout Earth's mantle in partially serpentinized lithosphere. Nature Geoscience 10, 222-228 (2017).

367

368

369

370

371

372

373 to ozone than previously estimated? Science $209,491-493$ (1980).

374

375

23 Daniel, J., Solomon, S., Portmann, R. \& Garcia, R. Stratospheric ozone destruction: The importance of bromine relative to chlorine. Journal of Geophysical Research: Atmospheres 104, 23871-23880 (1999).

37924 Kendrick, M. A., Kamenetsky, V. S., Phillips, D. \& Honda, M. Halogen systematics 

$(\mathrm{Cl}, \mathrm{Br}, \mathrm{I})$ in mid-ocean ridge basalts: a Macquarie Island case study. Geochimica et Cosmochimica Acta 81, 82-93 (2012).

382

25 Basu, Asish R., et al. High- ${ }^{3} \mathrm{He}$ plume origin and temporal-spatial evolution of the Siberian flood basalts. Science 269 (5225), 822-825 (1995).

26 Kelley, S. \& Wartho, J. Rapid kimberlite ascent and the significance of Ar-Ar ages in xenolith phlogopites. Science 289, 609-611 (2000).

388

389

27 Alexeev, S. et al. Isotopic composition $(\mathrm{H}, \mathrm{O}, \mathrm{Cl}, \mathrm{Sr})$ of ground brines of the Siberian Platform. Russian Geology and Geophysics 48, 225-236 (2007).

395

29 Aiuppa, A. et al. Emission of bromine and iodine from Mount Etna volcano.

398

30 Ross, P.-S. et al. Mafic volcaniclastic deposits in flood basalt provinces: a review. Journal of Volcanology and Geothermal Research 145, 281-314 (2005).

401

402

31 Millard, G. A., T. A. Mather, D. M. Pyle, William I. Rose, and B. Thornton. "Halogen emissions from a small volcanic eruption: Modeling the peak concentrations, dispersion, and volcanically induced ozone loss in the stratosphere." Geophysical 
40732 Burgess, S. D., \& Bowring, S. A. High-precision geochronology confirms voluminous 408 magmatism before, during, and after Earth's most severe extinction. Science Advances, 1(7) (2015).

410

33 Westrich, H. R., \& Gerlach, T. M. Magmatic gas source for the stratospheric $\mathrm{SO}_{2}$ cloud from the June 15, 1991, eruption of Mount Pinatubo. Geology, 20(10), 867-870 (1992).

414

34 Shaw, D. M. Trace elements in magmas: a theoretical treatment, Cambridge University Press (2006).

41835 Joachim, B. et al. Experimental partitioning of $\mathrm{F}$ and $\mathrm{Cl}$ between olivine, orthopyroxene and silicate melt at Earth's mantle conditions. Chemical Geology 416, 65-78 (2015).

36 Visscher, H., Looy, C. V., Collinson, M. E., Brinkhuis, H., Van Konijnenburg-Van Cittert, J. H., Kürschner, W. M., \& Sephton, M. A. Environmental mutagenesis during the end-Permian ecological crisis. Proceedings of the National Academy of Sciences of the United States of America, 101(35), 12952-12956 (2004).

42737 Benca, Jeffrey P., Ivo AP Duijnstee, and Cindy V. Looy. "UV-B-induced forest sterility: Implications of ozone shield failure in Earth's largest extinction." Science advances 4.2 (2018) 
43138 Baresel, B., Bucher, H., Bagherpour, B., Brosse, M., Guodun, K., \& Schaltegger, U. 432 Timing of global regression and microbial bloom linked with the Permian-Triassic boundary mass extinction: implications for driving mechanisms. Scientific Reports, 7,

39 Chavrit, D. et al. The contribution of hydrothermally altered ocean crust to the mantle halogen and noble gas cycles. Geochimica et Cosmochimica Acta 183, 106-124

438 (2016).

439

40 Jacob, D., Jagoutz, E., Lowry, D., Mattey, D. \& Kudrjavtseva, G. Diamondiferous eclogites from Siberia: remnants of Archean oceanic crust. Geochimica et Cosmochimica Acta 58, 5191-5207 (1994).

$44441 \quad$ Eiler, J. M. Oxygen isotope variations of basaltic lavas and upper mantle rocks. Reviews in mineralogy and geochemistry 43, 319-364 (2001).

42 Svensen, H., Jamtveit, B., Banks, D. A. \& Austrheim, H. Halogen contents of eclogite facies fluid inclusions and minerals: Caledonides, western Norway. Journal of Metamorphic Geology 19, 165-178 (2001).

451

43 Philippot, P., Agrinier, P., \& Scambelluri, M. Chlorine cycling during subduction of altered oceanic crust. Earth and Planetary Science Letters, 161(1-4), 33-44 (1998). 
45544 Callegaro, S. et al. Microanalyses link sulfur from large igneous provinces

456 and Mesozoic mass extinctions. Geology 42, 895-898 (2014).

457

$45845 \quad$ Foley, S.F. and Fischer, T.P., An essential role for continental rifts and

459 lithosphere in the deep carbon cycle. Nature Geoscience, 10(12), 897-902

460 (2017)

461

462

46 Muramatsu, Y. et al. Halogen concentrations in pore waters and sediments of the

463 Nankai Trough, Japan: Implications for the origin of gas hydrates. Applied

464 Geochemistry 22, 534-556 (2007).

465

466 Acknowledgments

467 This work is dedicated to L. A. T, who passed away in 2017. L. A. T. devoted his life 468 to science and teaching, serving as an excellent mentor to P. H. B. during his time at 469 University of Tennessee. This work was financially supported though a NERC 470 studentship NE/J500057/1 (to M. W. B.) and a NERC (NE/M000427/1) and ERC 471 (ERC-267692 NOBLE) grant to C. J. B. and R. B. P. H. B. was funded by an NSF 472 fellowship (EAR-114455) to investigate the geochemical signatures in these 473 samples. 
476 M. W. B, P. H. B and R. B conceived the project and prepared the initial manuscript.

477 L.A.T provided the samples and M. W. B and R. B performed the analysis. All 478 authors contributed to data analysis and preparation of the final manuscript.

479

480 Competing financial interests

481 The authors declare no competing financial interests.

482

483 Figure Captions

484 Figure 1. Halogen and $\mathrm{K}$ abundances in Udachnaya and Obnazhennaya 485 xenoliths. Abundances of (a) $\mathrm{Br}$, (b) I and (c) $\mathrm{K}$ plotted against $\mathrm{Cl}$ showing the 486 enrichment of $\mathrm{Br}$ and I within the Siberian SCLM relative to the MORB/OIB mantle 487 source and seawater ${ }^{24}$. Crushing ("crush") data are shown by open symbols and 488 stepped-heating ("melt”) by closed symbols. Errors bars are consistently covered by 489 symbol. Uncertainties are presented at $1 \sigma$.

490

491

Figure 2. Halogen composition of the Siberian SCLM. $\mathrm{Br} / \mathrm{Cl}$ versus $\mathrm{I} / \mathrm{Cl}$ (a) 492 crushing and (b) step heating of the Udachnaya and Obnazhennaya xenoliths. 493 Xenoliths show a range of halogen compositions which overlap the range of $\mathrm{Br} / \mathrm{Cl}$ 494 and $\mathrm{I} / \mathrm{Cl}$ observed in altered oceanic crust (AOC fluids) and eclogites. Seawater 495 evaporation trend (SET) is shown, indicating that sedimentary brines cannot be 496 responsible for the halogen signature of the xenoliths. $\mathrm{Br} / \mathrm{Cl}$ and $\mathrm{I} / \mathrm{Cl}$ results from 497 halogen fractionation (black arrows) of AOC fluids (green star). Seawater, marine 
498 pore fluids and MORB/OIB compositions are shown for reference ${ }^{24,46}$. Figure 499 symbols are the same as in Figure 1. Uncertainties are $1 \sigma$.

500

501 Figure 3. Helium isotopes and halogen systematics. ${ }^{3} \mathrm{He} /{ }^{4} \mathrm{He}$ versus (a) $\mathrm{I} / \mathrm{Cl}$ and

502 (b) $\mathrm{Br} / \mathrm{Cl}$ from crushed release of Udachnaya and Obnazhennaya xenoliths.

503 Udachnaya has ${ }^{3} \mathrm{He} /{ }^{4} \mathrm{He}, \mathrm{Br} / \mathrm{Cl}$ and $\mathrm{I} / \mathrm{Cl}$, which range from values similar to seawater

504 (blue star) towards higher $\mathrm{Br} / \mathrm{Cl}$ and $\mathrm{I} / \mathrm{Cl}$ and lower ${ }^{3} \mathrm{He} /{ }^{4} \mathrm{He}$ characteristic subduction

505 modified seawater. Obnazhennaya has higher ${ }^{3} \mathrm{He} /{ }^{4} \mathrm{He}$ ranging from Udachnaya-like

506 towards OIB-like values, from the influx of plumes melts. Mixing lines $[r=$

$\left.507\left({ }^{4} \mathrm{He} / \mathrm{Cl}\right)_{\text {plume }} /\left({ }^{4} \mathrm{He} / \mathrm{Cl}\right)_{\text {ScLm }}\right]$ shown between a hypothetical SCLM component (black

508 diamond, intercept through the data) and plume melts with the relative percentage of

509 SCLM assimilation shown. Figure symbols are same as used in Figure 1.

510 Uncertainties are $1 \sigma$.

512 Figure 4. Schematic of plume-lithosphere interaction within the Siberian

513 craton. a) SCLM is composed partly of metasomatised peridotite from addition of

514 subducted volatiles, which potentially seeds diamond formation. b) Intermittent

515 influence of the Siberian plume drives kimberlite volcanism c) Plume melt impinges

516 on the lithosphere, incorporating volatile rich SCLM material. Halogens released to

517 the atmosphere during explosive SFB eruptions leading to the extensive ozone 518 depletion. d) Plume retreats leaving a much-reduced SCLM with veins of melt 519 residue, followed by a second period of kimberlitic volcanism, transporting melt 520 residues and SCLM material to the surface. 


\section{Methods}

\section{Neutron irradiation noble gas mass spectrometry (NI-NGMS)}

524 Olivine and clinopyroxene mineral separates from Udachnaya and Obnazhennaya 525 peridotite xenoliths were selected for heavy halogen $(\mathrm{Cl}, \mathrm{Br}$ and $\mathrm{I})$ and $\mathrm{K}$ analysis

526 using neutron-irradiated noble gas mass spectrometry (NI-NGMS) ${ }^{47-52}$. Samples 527 weighing between 0.015 and $0.062 \mathrm{~g}$ were first cleaned with deionised water in an 528 ultrasonic bath for 20 minutes, followed by a further 5 minutes in acetone. Samples 529 were then dried under a heat lamp at $100^{\circ} \mathrm{C}$, wrapped in $\mathrm{Al}$ foil and sealed in 530 evacuated fused-silica tubes together with $\mathrm{Hb} 3 \mathrm{gr}$, scapolite and Shallowater 531 meteorite standards to monitor noble gas proxy production from $\mathrm{K}$ and halogens ${ }^{51}$.

533 Samples were irradiated in the GRICIT (MN2014b) facilities of the TRIGA Reactor, 534 Oregon State University for a few hours each day between 22/04/2014 and 535 01/07/2014 giving a total irradiation time of 205 hours. Irradiation details and monitor 536 values for this irradiation have been reported previously ${ }^{51}$.

538 Noble gas proxy isotopes $\left({ }^{38} \mathrm{Ar}_{\mathrm{Cl}},{ }^{80} \mathrm{Kr}_{\mathrm{Br}},{ }^{128} \mathrm{Xe}_{\mathrm{I}}\right.$ and $\left.{ }^{39} \mathrm{Ar}_{\mathrm{K}}\right)$ formed during irradiation as 539 well as natural $\mathrm{Ar}, \mathrm{Kr}$ and $\mathrm{Xe}$ isotopes were measured on the MS1 mass 540 spectrometer ${ }^{52}$. A subset of samples and repeat analyses were also performed on a

541 Thermo Fisher Scientific ARGUS VI mass spectrometer ${ }^{51}$. Noble gases were firstly 542 extracted from trapped fluid inclusions by loading samples into hand-operated 
543 modified Nupro $^{\circledR}$ valve crushers $^{53}$ (MS1 mass spectrometer). For bulk sample

544 analysis, powders from crushing analyses were loaded into in a tantalum resistance

545 furnace (MS1) and step heated using four temperature steps of $600^{\circ} \mathrm{C}, 1000^{\circ} \mathrm{C}$,

$5461400^{\circ} \mathrm{C}$ and $1600^{\circ} \mathrm{C}$ to release halogens contained within the mineral matrix.

547 Halogens from four samples (UV33, UV88, UV357 and 0129-74) were extracted

548 using a $10.6 \mu \mathrm{m}$ wavelength $\mathrm{CO}_{2}$ laser (Teledyne $\mathrm{CETAC}$ Fusions $\mathrm{CO}_{2}-\mathrm{ARGUS}$

$549 \mathrm{VI}$ ). In order to test that both extraction methods gave the similar results, sample

550 097-12 was analysed using both the furnace and laser, $\mathrm{Br} / \mathrm{Cl}$ and $\mathrm{I} / \mathrm{Cl}$ varied by less

551 than $20 \%$ and $35 \%$ respectively between laser and furnace extraction suggesting

552 halogens were released in similar proportions using both extraction methods.

553 Halogens abundances were then calculated using the well-defined conversion

554 standards with known halogen concentrations (Hb3gr, scapolite and Shallowater

555 meteorite $)^{50,51}$, which monitor the efficiency of noble gas production through thermal 556 and epithermal neutron reactions.

558 Air calibrations and blanks were analysed daily to check the sensitivity and 559 background of the spectrometers, with maximum furnace blank values at $1600^{\circ} \mathrm{C}$ on 560 the MS1 being $1.65 \times 10^{-10} \mathrm{~cm}^{3}$ STP ${ }^{40} \mathrm{Ar}, 2.92 \times 10^{-13} \mathrm{~cm}^{3} \mathrm{STP}{ }^{84} \mathrm{Kr}$ and $3.54 \times 10^{-14}$ 561 STP $\mathrm{cm}^{3}{ }^{132} \mathrm{Xe}$ and ARGUS VI blanks being $5.76 \times 10^{-12} \mathrm{~cm}^{3}$ STP ${ }^{40} \mathrm{Ar}$ and $1.41 \times$ $56210^{-15} \mathrm{~cm}^{3}$ STP ${ }^{132} \mathrm{Xe}$, with $\mathrm{Kr}$ blanks below detection limit. Noble gas purification 563 analytical procedures for the MS1 and ARGUS VI mass spectrometers as well as the 564 data reduction procedures have been documented previously ${ }^{52,5 e ́}$. External precision 565 is reported at $3 \%(1 \sigma)$ for $\mathrm{Cl}$ and $7 \%(1 \sigma)$ for $\mathrm{Br}$ and I determinations. 


\section{Data availability}

568 All data pertaining to this study is presented in the paper and the supplementary 569 information. Correspondence and requests for materials should be addressed to the 570 corresponding author.

571

572 Method References

57347 Merrihue, C. \& Turner, G. Potassium-argon dating by activation with fast neutrons.

$574 \quad$ Journal of Geophysical Research 71, 2852-2857 (1966).

575

57648 Böhlke, J. \& Irwin, J. Laser microprobe analyses of $\mathrm{Cl}, \mathrm{Br}$, I, and $\mathrm{K}$ in fluid inclusions:

577 Implications for sources of salinity in some ancient hydrothermal fluids. Geochimica $578 \quad$ et Cosmochimica Acta 56, 203-225 (1992).

579

58049 Johnson, L., Burgess, R., Turner, G., Milledge, H. \& Harris, J. Noble gas and 581 halogen geochemistry of mantle fluids: comparison of African and Canadian 582 diamonds. Geochimica et Cosmochimica Acta 64, 717-732 (2000).

583

$58450 \quad$ Kendrick, M. A. High precision $\mathrm{Cl}, \mathrm{Br}$ and I determinations in mineral standards using 585 the noble gas method. Chemical Geology 292, 116-126 (2012).

586

$58751 \quad$ Ruzié-Hamilton, L. et al. Determination of halogen abundances in terrestrial and 588 extraterrestrial samples by the analysis of noble gases produced by neutron 589 irradiation. Chemical Geology 437, 77-87 (2016).

590 
59152 Broadley, M. W., Ballentine, C. J., Chavrit, D., Dallai, L. \& Burgess, R. Sedimentary 592 halogens and noble gases within Western Antarctic xenoliths: Implications of 593 extensive volatile recycling to the sub continental lithospheric mantle. Geochimica et 594 Cosmochimica Acta 176, 139-156 (2016).

595

59653 Stuart, F. \& Turner, G. The abundance and isotopic composition of the noble gases 597 in ancient fluids. Chemical Geology: Isotope Geoscience section 101, 97-109 (1992).

598 


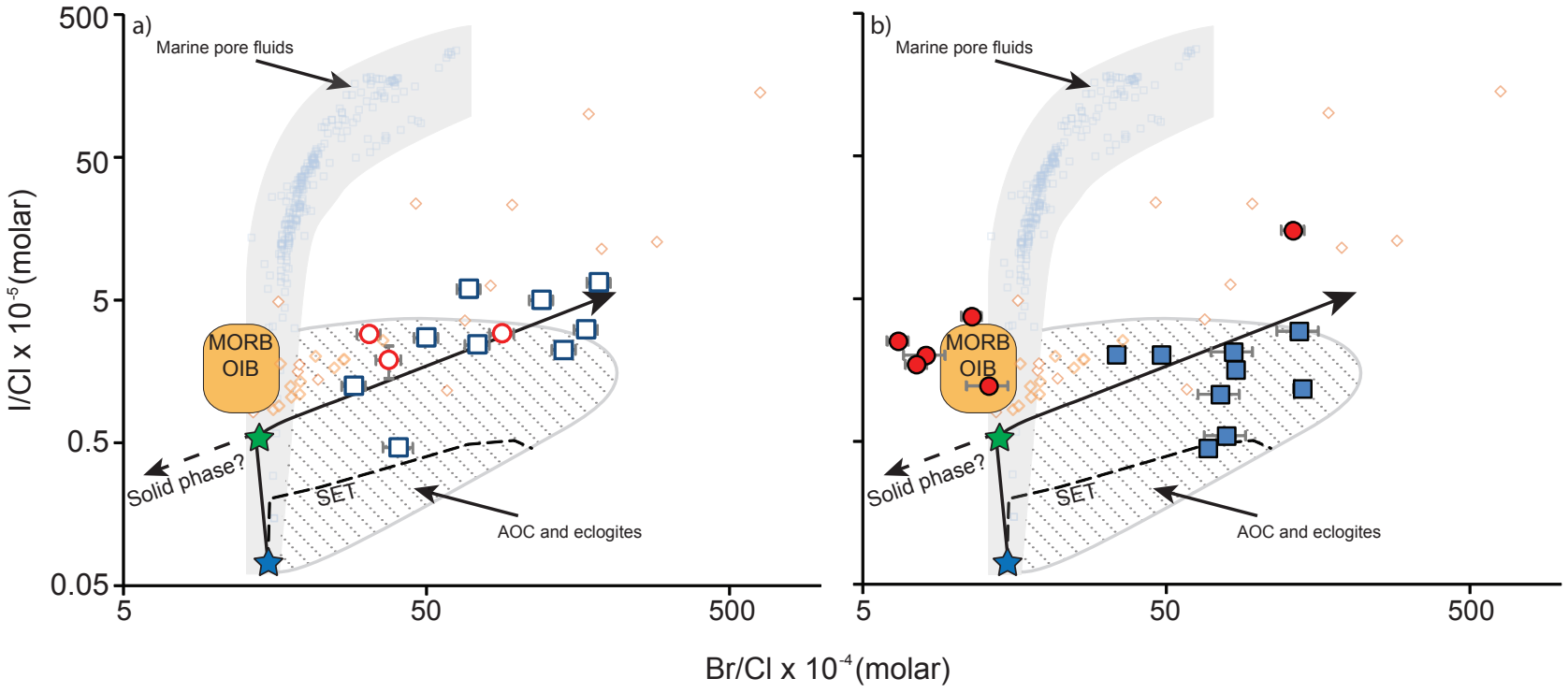

$\checkmark$ Starting fluid $\Delta$ Modern seawater $\diamond$ Canadian diamonds 
360 Ma Metasomatic episodes
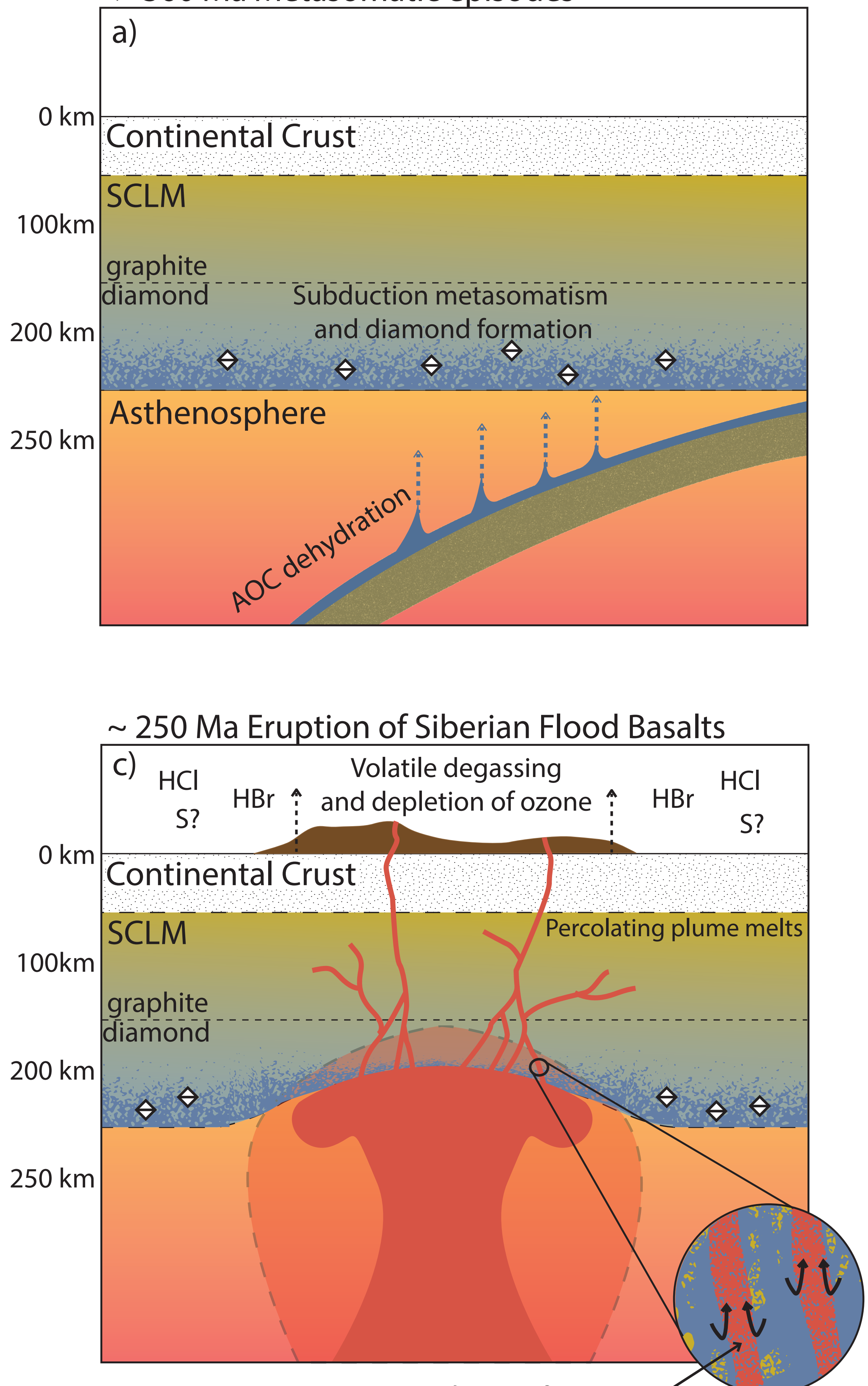

Assimilation of metasomatised SCLM into rising melts

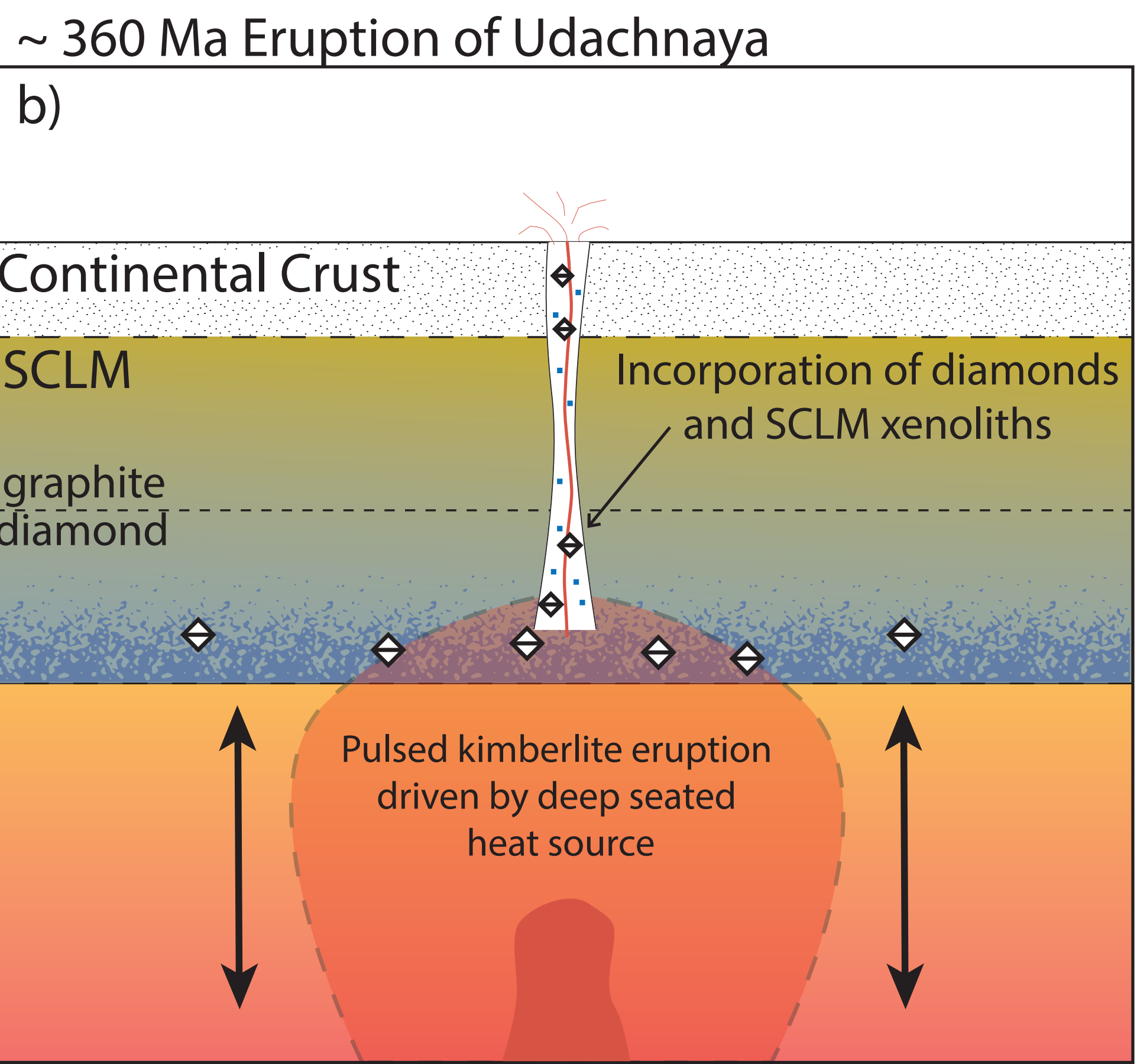

160 Ma Eruption of Obnazhennaya

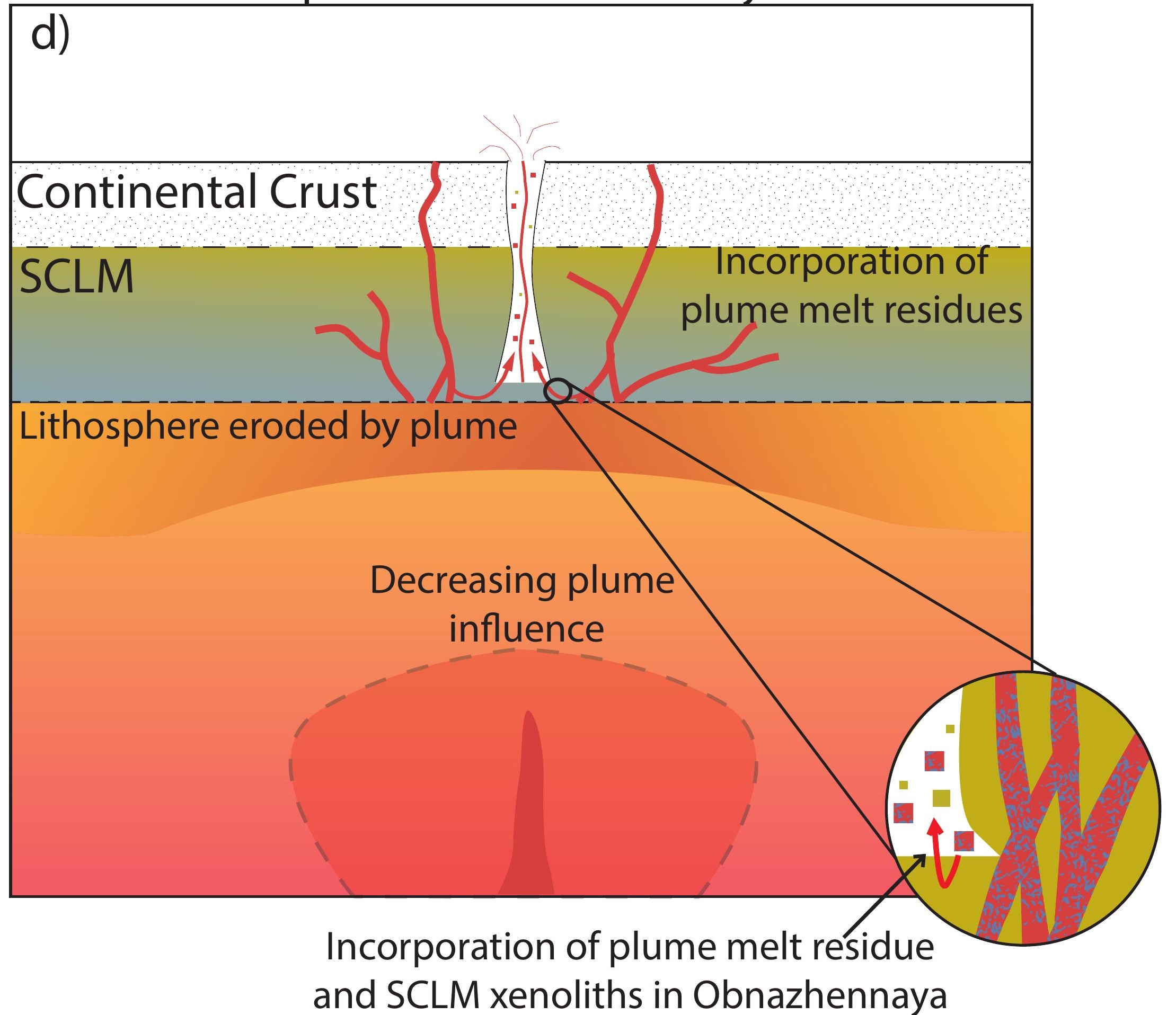


